MoHd Noor, A.G. and NAIMAH IBRAHAM (1986): Characterization and evaluation of Hevea Germplasm. IRRDB Symposium, 11-13 Nov 1986, Malaysia.

ONG, S. H. and H. TAN (1987): Utilization of Hevea genetic resources in the RRIM. Malaysian Applied Biology 16: 145-155.

OnG, S. H., M. N. B. GHani, A. M. TAN and H. TAN (1983): New Hevea Germplasm: Its introduction and potential. Proceedings of RRIM Planters' Conference, 1983, pp. 3-17.

POLLINERE, J. P. (1966): Introduction to the study of genetical selection of Hevea brasiliensis. Tropical abstracts 21: 6 .

PooL, R. W. (1974): An Introduction of Quantitative Ecology, McGraw-Hill, New York.

RAO, G. P., C. P. ReGHU and P. J. George (1999): Evaluation of Hevea germplasm. VIII. Variability in certain juvenile characters of wild Hevea germplasm. Journal of Cytology and Genetics 34(2): 183-186.

RaO, G. P., S. T. Abraham, C. P. Reghu and Y. A. Varghese (2005): Descriptors for Rubber (Hevea brasiliensis Willd. ex Adr. de Juss.) Muell. Arg. Rubber Research institute of India, Kottayam, India. pp. 72.

RAO, G. P. and Y. A. VARGhese (2011): Early yield and growth performance of Hevea germplasm in India. Advances in Plant Sciences 24(2): 433-437.
SCHUltes, R. E. (1977): Wild Hevea: An untapped source of germplasm. Journal of Rubber Research Institute of Sri Lanka 54: 227-257.

SETHURAJ, M. R. (1985): Physiology of growth and yield in Hevea brasiliensis. Proceeding of the International Rubber Conference, 1985, Kuala Lumpur, Malaysia, Vol. 3, pp. 3-19.

SHARMA, J. R. (1988): Statistical and Biometrical techniques in plant breeding. New Age Int. Publishers, New Delhi.

Simmonds, N. W. (1989): Rubber Breeding. In: Rubber (Eds. C. C. Webster and W. J. BAUlKWILl) Longman Scientific and Technical, New York.

TAN, H. (1987): Strategies in rubber tree breeding. In: Improving Vegetatively Propagated Crops. (Eds. A. U. CAmpbell, A. J. Aввот and R. K. AtKIn). Academic Press, London, pp 27-62.

WANG, Y. P., P. G. JARVIS and C. M. A. TAYLOR (1991): PAR absorption and its relation to above ground dry matter production of Sitka spruce. Journal of Applied Ecology 28: $547-560$.

Wycherly, P.R. (1968): Introduction of Hevea to the Orient. The Planter 44: 127-137.

\title{
Clinal variation in Pinus hartwegii populations and its application for adaptation to climate change
}

\author{
By E. Loya-Rebollar ${ }^{1)}$, C. SÁenz-Romero ${ }^{1), *}$, R. A. Lindig-Cisneros ${ }^{2)}$, \\ P. Lobit ${ }^{1)}$, J. A. VILlegas-MORENO ${ }^{3)}$ and N. M. SÁNCHEZ-VARGAS ${ }^{1)}$
}

(Received $1^{\text {st }}$ June 2012)

\begin{abstract}
In order to determine the genetic variation among populations of Pinus hartwegii along altitudinal gradients, and the possible adaptive decoupling due to climatic change, a common garden test was set up with 13 provenances collected along an altitudinal transect (3150 to 3750 masl; collection sites were every $50 \mathrm{~m}$ of altitudinal difference) from Pico de Tancítaro, Michoacán, west-central Mexico. The test evaluated

1) Instituto de Investigaciones Agropecuarias y Forestales, Universidad Michoacana de San Nicolás de Hidalgo (IIAFUMSNH). Km 9.5 carretera Morelia-Zinapécuaro, Tarímbaro, Michoacán 58880, México.

2) Laboratorio de Ecología de Restauración, Centro de Investigaciones en Ecosistemas, Universidad Nacional Autónoma de México. Apartado Postal 27, Administración 3, Santa María, Morelia, Michoacán 58091, México.

$\left.{ }^{3}\right)$ Instituto de Investigaciones Químico-Biológicas, Universidad Michoacana de San Nicolás de Hidalgo (IIQB-UMSNH). Edificio B-3, Ciudad Universitaria, Av. Francisco J. Mujica s/n Col. Felícitas del Río, Morelia, Michoacán 58030, México.

*) Corresponding author: Cuauhtémoc SÁEnz-Romero. Phone +52 (443) 334-0475, ext 118. E-Mail: csaenzromero@gmail.com
\end{abstract}

trees aged 4.5 to 5.5 years, and contemporary and future (year 2030; six model-emission scenarios) climate variables were estimated. We found significant $(P<0.005)$ differences among populations in total elongation, final seedling height, basal diameter, rate of elongation, dry weight of needles, branches and stem, total dry weight and first principal component. We found a significant association between population performance, expressed as first principal component values, and their climate, where the best climatic predictor was the frost free period $\left(r^{2}=0.90, P<0.0001\right)$. This result indicates that the patterning of genetic differentiation among populations is strongly associated with a climatic and altitudinal gradient. We propose a re-delineation of fixed climatic and altitudinal seed zoning for seed and seedling movement, based on intervals of 26 days of difference of frost free period: Zone 1, from 240 to 214 days of frost free period or 12 to $11^{\circ} \mathrm{C}$ or 3150 to 3350 masl; Zone 2, 214 to 188 days or 11 to $10^{\circ} \mathrm{C}$ or 3350 to 3550 masl; and Zone 3,188 to 162 days or 10 to $9^{\circ} \mathrm{C}$ or 3550 a 3750 masl. Projecting at what altitude will occur the same frost free period values by year 2030, we suggested that populations should be shifted $400 \mathrm{~m}$ attitudinally upward, through a program of assisted migration, aiming to 
realign the populations to the climate for which they are adapted. Seedling deployment should use future (year 2030) fixed seed zones, with the same projected climatic interval values than contemporary climate, although at the following altitudinal limits: Zone $1_{2030}$, from 3550 to 3750 masl; Zone $2_{2030}$, 3750 to 3950 masl; and Zone $3_{2030}$, 3950 to 4150 masl.

Key words: Pinus hartwegii, provenance, altitudinal genetic variation, seedling height, shoot elongation, dry weight, climatic change, zoning, assisted migration.

\section{Introduction}

Pinus hartwegii Lindl is a pine species from the temperate-cold zones of Mexico and Central America that grows at altitudes between 3000 to $4000 \mathrm{~m}$, along timberline (LAUER, 1978; PERRY, 1991). Its extreme altitudinal distribution makes $P$. hartwegii a species highly vulnerable to global warming, which could reduce its exclusive habitat (Gomez-MendozA and ArriagA, 2007). By the end of the current century, suitable climates for the conifer forests in the Trans-Mexican Volcanic Belt in México, where $P$. hartwegii populations naturally occur, may be reduced $92 \%$ (REHFELD et al., 2012). There is mounting evidence that rear-end populations (those at the lower altitudinal limit in the case of tree species distributed in mountain ranges) are entering a process of decline, apparently due to drought and heat stress linked to climatic change (Allen et al., 2010; MátYÁs, 2010).

Estimation of potential decoupling (due to climatic change) between conifer populations and the climate for which they are adapted and definition of management actions aiming to realign genotypes to their suitable environments require comprehension of (a) the pattern of genetic variation along altitudinal gradients, (b) the association between populations and the climate for which they are adapted, and (c) an estimation of where and when in the future a given climate suitable for a given population will occur (TCHEBAKOVA et al., 2005; SÁEnZ-Romero et al., 2006; SÁEnZ-Romero et al., 2012a).

The patterning of genetic variation among populations for $P$. hartwegii quantitative traits was studied in 18month-old seedlings by ViVEROS-VIVEROs et al (2009). An altitudinal cline was found, and $350 \mathrm{~m}$ wide altitudinal seed zones were delineated. However, it is important to confirm such patterning at older ages. There is also a previous study of isoenzymatic variation among P. hartwegii population (VIVERos-VIVERos et al., 2010), but it does not provide answers about performance of adaptive traits.

The objectives of the research were (a) to determine whether genetic differences exist among populations for seedling height, diameter, patterning of shoot elongation and biomass accumulation for Pinus hartwegii seedlings originating at different altitudes on Pico de Tancítaro, Michoacán, central-west México, (b) to re-delineate an altitudinal seed zoning developed previously by Viveros-Viveros et al. (2009), and (c) to estimate the altitudinal shift needed to realign contemporary populations to the sites where, by the year 2030, the climate for which they are adapted will occur.

\section{Materials and Methods}

\section{Seed collection and test establishment}

Open-pollinated seeds were collected in January 2005 from 13 Pinus hartwegii populations in Pico de Tancítaro National Park, Michoacán, central-west Mexico. Seed was collected along an altitudinal transect from 3150 masl to 3750 masl, with one population collected every $50 \mathrm{~m}$ of altitudinal difference (Table 1, Figure 1). Those populations are the same as those studied by ViVERos-ViVERos (2009, 2010), although we verified and corrected provenance altitudes (adding $150 \mathrm{~m}$ of altitude to each provenance). The trees represented by these samples are termed populations, while the location of a population is called the provenance.

Seedlings were grown for 19 months under the nursery conditions described by VIVEROs-VIVERos et al. (2009). After the nursery stage, seedlings were transplanted to a common garden test, in which conditions consisted of two raised rectangular wooden beds, each $12.3 \mathrm{~m}$ long $\mathrm{x} 1.5 \mathrm{~m}$ wide $\mathrm{x} 0.6 \mathrm{~m}$ high; the wooden structures were filled with a 20 -cm layer of coarse extrusive volcanic gravel to improve drainage (particle size: $28.4-37.3 \mathrm{~mm}$ ), and on top of that, a $40 \mathrm{~cm}$ layer of a $4: 1$ mixture of local Andosol pine-oak forest top-soil and commercial Creciroot ${ }^{\circledR}$ substrate. Seedlings were placed in a randomized complete block design, with five blocks, 13 populations, plots of five-seedlings in a row, spaced $0.3 \mathrm{~m}$ within plots $0.3 \mathrm{~m}$ apart. The first and the last plot of each wooden structure were flanked by a row of randomly selected seedlings to control the edge effect. The test was covered by a $35 \%$ shade net. Test was located at the Universidad Michoacana de San Nicolás de Hidalgo, Morelia, Michoacán (101¹4'59"W, $19^{\circ} 41^{\prime} 20^{\prime \prime} \mathrm{N}, 1955$ masl, mean annual temperature $17.0^{\circ} \mathrm{C}$, average annual precipitation $881 \mathrm{~mm}$; see loca-

Table 1. - Geographic and altitudinal location of the Pinus hartwegii Lindl. populations in Pico de Tancítaro National Park, Michoacán, Mexico.

\begin{tabular}{|c|c|c|c|}
\hline Population & I atitude (N) & I angitude (W) & Altitude (masl) \\
\hline 1 & $19^{\circ} 25.120^{\prime}$ & $102^{\circ} 18.750^{\circ}$ & 3750 \\
\hline 2 & $19^{\circ} 25.111^{\prime}$ & $102^{\circ} 18.599^{\circ}$ & 3700 \\
\hline 3 & $19^{\circ} 25.179^{\prime}$ & $102^{\circ} 18.589^{\circ}$ & 3650 \\
\hline 4 & $19^{\circ} 25.046^{\circ}$ & $102^{\circ} 18.331^{\prime}$ & 3600 \\
\hline 5 & $19^{\circ} 25.128^{\prime}$ & $102^{\circ} 18.399^{\circ}$ & 3550 \\
\hline 6 & $19^{\circ} 25.327^{\prime}$ & $102^{\circ} 18.325^{\circ}$ & 3500 \\
\hline 7 & $19^{\circ} 25.416^{\circ}$ & $102^{\circ} 18.187^{\circ}$ & 3450 \\
\hline 8 & $19^{\circ} 25.722^{\prime}$ & $102^{\circ} 18.123^{\circ}$ & 3400 \\
\hline 9 & $19^{\circ} 26.036^{\circ}$ & $102^{\circ} 17.998^{\prime \prime}$ & 3350 \\
\hline 10 & $19^{\circ} 26.094^{\circ}$ & $102^{\circ} 17.786^{\circ}$ & 3300 \\
\hline 11 & $19^{\circ} 26.221^{\prime}$ & $102^{\circ} 17.454^{\prime}$ & 3250 \\
\hline 12 & $19^{\circ} 26.292^{\prime \prime}$ & $102^{\circ} 17.252^{\circ}$ & 3200 \\
\hline 13 & $19^{\circ} 25.967^{\prime}$ & $102^{\circ} 16.972^{\prime}$ & 3150 \\
\hline
\end{tabular}


tion in Figure 1). Plants were irrigated as needed to cope with much warmer conditions than those of natural stands; no irrigation would have resulted in severe mortality in the experiment; we preferred to avoid that, although we know that growth might be different from performance that could be obtained if the experiment were placed near or inside natural stands.

When seedlings were four years and seven months old (early February 2010), just before initiation of shoot elongation, seedling height $(\mathrm{mm})$ was evaluated every two weeks for four months, and then every 3 weeks for three months until growth ceased (end of August 2010, five years and two months old). Height was measured with a ruler supported by an aluminum bar to standardize the measurements. Basal diameter $(\mathrm{mm})$ was also measured at the end of the growing season.

In December 2010, when seedlings were five years and six months old, the aerial part of the seedlings was harvested to determine dry weight. Needles, branches and stem were dried separately in an oven (Feliza ${ }^{\circledR}$, México) at $60^{\circ} \mathrm{C}$ for 72 hours. Large stems were fragmented to facilitate drying. Dry weight was measured using a scale $\left(\right.$ Ohaus $^{\circledR}$, Canada; $\left.0.00 \mathrm{~g}\right)$. Dry weight of the aerial part of the seedling was derived by adding dry weights of needles, branches and stem; this will herein be referred to as simply total dry weight.

\section{Data analysis}

Logistic growth function for total height was fit for each individual seedling, using PROC NLIN of SAS (2004) and the following model (SÁENZ-Romero et al., 2012b):

$$
\mathrm{Y}_{i}=1 /\left(1+\mathrm{e}^{\left(\beta_{0}+\beta_{1} \times+\left(\beta_{1} / \mathrm{X}\right)\right)}\right)
$$

where $\mathrm{Y}_{i}=$ observation on the $i^{\text {th }}$ seedling (total height); $\beta_{0}, \beta_{1}$ and $\beta_{2}$ are regression parameters and $X=$ measurement date (Julian day).

Regression parameters $\left(\beta_{0}, \beta_{1}\right.$ and $\left.\beta_{2}\right)$ were used to estimate a growth curve of predicted values for each individual seedling, using the following model:

$$
\mathrm{P}_{i}=\left(1 /\left(1+\mathrm{e}^{\left(\beta_{0}+\beta_{1} \times+\beta_{2}(1 / \mathrm{X})\right)}\right)\right) \mathrm{Z}
$$

where $\mathrm{P}_{i}=$ predicted growth (total height) for the $i^{\text {th }}$ seedling; $\beta_{0}, \beta_{1}$ and $\beta_{2}$ are regression parameters; $\mathrm{X}=$ measurement date (Julian day) and $\mathrm{Z}=$ total elongation $(\mathrm{mm})$.

Variables used in analyses of genetic variation include total elongation (the difference between the final measurement of five-year- and two-month-old-seedling height and the initial seedling height obtained at four years and seven months of age), and basal diameter. We also used the regression models to estimate the day on which $2 \mathrm{~mm}$ of growth had occurred for each seedling, that is, the start of growth period in Julian days; the day on which all but $2 \mathrm{~mm}$ of growth had occurred, that is, the end or cessation of the growth period in Julian days; the rate of elongation between $20 \%$ and $80 \%$ of total elongation, that is, the maximum growth rate; and the number of days between start of growth and end of growth, or the duration of growth period.

These variables were used in an analysis of variance to test significance among populations, using PROC GLM of SAS (SAS, 2004). Ratio of variance component to total variance was estimated using PROC VARCOMP

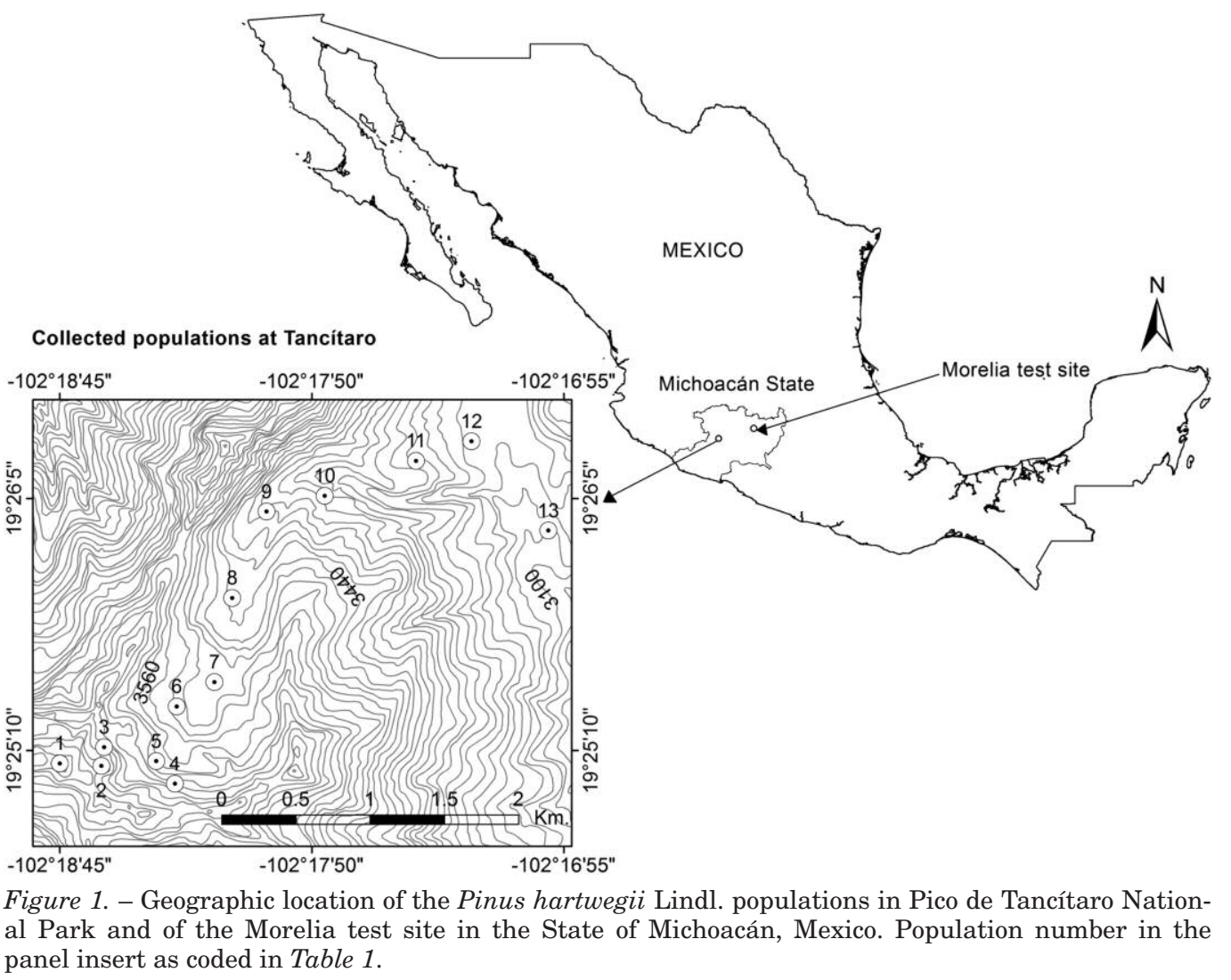


METHOD=REML (SAS, 2004). These analyses used the following statistical model:

$$
\mu_{i j k}=\mu+\mathrm{B}_{i}+\mathrm{P}_{j}+\mathrm{B}_{i} * \mathrm{P}_{j}+\varepsilon_{i j k}
$$

where $\mathrm{Y}_{i j k}=$ observation on the $k^{\text {th }}$ seedling of the $j^{\text {th }}$ population of the $i^{\text {th }}$ block, $\mu=$ overall mean, $\mathrm{B}_{i}=$ effect of $i^{\text {th }}$ block, $\mathrm{P}_{j}$ effect of the $j^{\text {th }}$ population, $\mathrm{B}_{i}{ }^{*} \mathrm{P}_{j}=$ interaction of population by block, and $\varepsilon_{i j k}=$ error term; $i=1, \ldots b, j=1, \ldots t$, and $k=1, \ldots n$, where $b=5, t=13, n=5$, which are the number of blocks, populations, and seedlings per plot, respectively.

In order to express the genetic differentiation among populations across several traits in a single variable, principal components were estimated from those quantitative traits that were significantly different among populations. Analysis was conducted using the PRINCOMP procedure of SAS (SAS, 2004). Total dry weight was eliminated from the principal component analysis to prevent self-correlation $(r>0.90)$ with other dry weight variables (needles, branches and stem).

The relationship between the environmental gradient (along the altitudinal transect) of the seed sources and genetic variation among populations was assessed by regressing the first principal component (PRIN1) against each one of 15 climatic variables representing the environmental gradient: Mean annual temperature (MAT, ${ }^{\circ} \mathrm{C}$ ), mean annual precipitation (MAP, mm), total precipitation in the growing season (April to September, GSP, mm), degree-days above $5{ }^{\circ} \mathrm{C}$ (DD5), negative degree-days calculated from minimum temperature (MINDD0), mean temperature in the coldest month (MTCM, ${ }^{\circ} \mathrm{C}$ ), mean minimum temperature in the coldest month (MMIN, $\left.{ }^{\circ} \mathrm{C}\right)$, mean temperature in the warmest month (MTWM, ${ }^{\circ} \mathrm{C}$ ), mean maximum temperature in the warmest month $\left(\mathrm{MMAX},{ }^{\circ} \mathrm{C}\right)$, Julian date of last spring frost (SDAY), Julian day of first fall frost (FDAY), length of frost-free season (FFP, days), degree-days above $5{ }^{\circ} \mathrm{C}$ in the frost-free season (GSDD5), Julian day on which DD5 sums to 100 (D100), and an annual aridity index $\left(\mathrm{AAI}=\mathrm{DD} 5^{0.5} / \mathrm{MAP}\right)$. Those climatic variables have demonstrated relevance as primary factors controlling the distribution of biomes and plant species (see TUHKANEN, 1980; REHFELDT, 2006; REHFELDT et al., 2006). Climatic values were estimated for the total of 13 Pinus hartwegii provenances for contemporary climate (average 1961-1990). Climate estimations were obtained from spline climate surfaces fitted from monthly average temperatures (mean, maximum and minimum) and monthly precipitations from numerous weather stations (see SÁENZ-Romero et al., 2010). Regression analysis was conducted testing one climatic variable at a time, because there was a strong correlation among climatic variables. Regression used a linear and a quadratic model with PROC REG (SAS, 2004). The linear model was:

$$
\mathrm{Y}_{i j}=\beta_{0}+\beta_{1} \mathrm{X}_{i}+\varepsilon_{i j}
$$

where $\mathrm{Y}_{i j}=$ population mean of the first principal component, $\beta_{0}=$ intercept, $\beta_{1}=$ slope, $X_{i}=$ value of a climatic variable of the $i^{\text {th }}$ population origin, $\varepsilon_{i j}=$ error.

The quadratic model was:

$$
\mathrm{Y}_{i j}=\beta_{0}+\beta_{1} \mathrm{X}_{i}+\beta_{2} \mathrm{X}_{i}^{2}+\varepsilon_{i j}
$$

We explored also selection of the best climatic variables conducting stepwise multiple regression analysis, using PROC REG (SAS, 2004).

\section{Seed zoning}

Differentiation along the cline was interpreted relative to the least significant difference (LSD, $\alpha=0.20$ ) for the first principal component. Then, climatic seed fixed zones were delimited by translating the LSD into an interval of climatic values that must separate populations before there can be reasonable certainty of genetic differentiation. (REHFELDT, 1991; SÁENZ-ROMERo et al., 2006; SÁEnz-Romero et al., 2012b). The equivalence of the LSD for the first principal component to climatic values were obtained from the regression models fitted.

The association between climatic variables and altitude (masl) was explored by conducting a regression analysis of the climatic variables against provenance altitude. Because there was a strong association between climatic values and altitude, climatic fixed seed zones were translated also to altitude, considering that forest managers find it easier to use altitude as a guideline for seed and seedling movement than climatic values. That is in part because topographic maps are widely available in México at different scales, but that is not the case of detailed climatic maps. Thus, altitudinal zoning done previously by Viveros-Viveros et al. (2009) was revisited.

\section{Estimation of future climatic variables}

Forecasted climate change estimates for the provenances for the decade centered in year 2030 (herein called year 2030) were obtained after refitting the spline climate surfaces with outputs of three global circulation models (GCMs) and two emission scenarios for each GCM: (1) Canadian Center for Climate Modeling and Analysis (CCCMA), using the CGCM3 (T63 resolution) model, SRES A2 and B1 scenarios; (2) Met Office, Hadley Centre (UKMO), using the HadCM3 model, SRES A2 and B2 scenarios; and (3) Geophysical Fluid Dynamics Laboratory (GFDL), using the CM2.1 model, SRES A2 and B1 scenarios. Data, their descriptions and an explanation of the scenarios are available from the Intergovernmental Panel on Climate Change Data Distribution Center (http://www.ipcc-data.org/). In general, the A2 scenario reflects unrestrained carbon emissions (the "pessimistic" scenario), while the B1 and B2 scenarios incorporate social and economic restraints (the "optimistic" scenarios) (IPCC 2000). See REHFELDT (2006) for a description of downscaling techniques and grid development and SÁEnz-Romero et al., (2010) for the Mexico extension. Point estimates for all climatic variables for each provenance were obtained by interrogating the spline climatic surfaces (contemporary and year 2030) by using a web-based interface (http://forest.moscowfsl. wsu.edu/climate/; CROOKSTON and REHFELDT, 2011), and then for the year 2030 estimation the six model-scenario estimates were averaged by provenance.

\section{Estimation of future seed zones}

To produce a simple guideline that can be applied in land-use management to realign contemporary popula- 
tions to inhabit in 2030 the same climate they inhabit today, we delineated year 2030 altitudinal seed zones that should be used to deploy at present seedlings originated from seed collected at the contemporary seed zones. The climate average 1961-1990 is the best representation that we have available of contemporary climate and is built in a spline climatic model (SÁENZROMERO et al., 2010). It is very important that the contemporary climate of reference does not continue shifting (to say for example 2000-2010 instead of 1961-1990), since the underlying assumption is that contemporary climate is that to which natural populations have adapted in an evolutionary process. Today's climate (average 2000-2010 or so) has already been affected by global warming. We chose the time horizon of the decade centered in year 2030 as the future climate target, because realigning the contemporary genotypes to a climate expected by year 2060 in a given site could expose the seedlings to frost damage today (SÁENZROMERo et al., 2012a).

We delineated future seed zones using as limits the same values of the frost free period that were used to define the contemporary seed zone limits. We chose that climatic variable in particular because it was the one that, under contemporary climate, best predicted the population average of the growth performance first principal component. However, in order to find the future equivalence in altitude of those frost free period values, we fit a regression (using Proc REG of SAS, 2004) using as dependent variable the average frost free period value averaging across six model-scenario projections, against altitude of each population (as the independent variable).

\section{Results and Discussion}

\section{Differences among populations}

There is a strong indication of genetic differentiation among populations for quantitative traits. Differences among populations were significant for total elongation, $(P=0.0008)$, rate of elongation $(P=0.0014)$, final seedling height $(P=0.0150)$, basal diameter $(P<0.0001)$, dry weight of needles $(P=0.0001)$, branches $(P=0.0045)$, stem $(P=0.0027)$, and total dry weight $(P=0.0003)$ (Table 2). Differences among populations were as large as $23.3 \%$ of the contribution to total variance for basal diameter.

Apparently, what caused differences among populations was the rate of elongation, rather than the duration of the growth period since there were no significant differences among populations for start, end or duration of the growth period.

There were no significant differences among blocks or for the interaction block by population for any of the studied variables, except for duration of the growth period $(P=0.0437)$ for the interaction block by population. The lack of significance among blocks indicates that the common garden test had relatively homogeneous environmental conditions (substrate, shade, irrigation regimen, weeding, etc.) across blocks.

Principal component analysis was conducted including total elongation, rate of elongation, final seedling height, basal diameter and dry weight for needles, branches and stem. It resulted in a first principal component (PRIN1) with an eigenvalue of 5.1 containing $73.1 \%$ of the total variation. The second principal component had an eigenvalue of only 0.7 contributing $10.6 \%$

Table 2. - Analysis of variance for 5.5-year-old seedlings from 13 Pinus hartwegii populations. Percent of contribution to total variance (\%) and significance values $(\mathrm{P})$.

\begin{tabular}{|c|c|c|c|c|c|c|c|}
\hline \multirow[t]{2}{*}{ Trails } & \multicolumn{2}{|c|}{ Population } & \multicolumn{2}{|c|}{ Block } & \multicolumn{2}{|c|}{ Population* $\left.{ }^{*}\right|_{0}$} & \multirow{2}{*}{$\begin{array}{c}\text { Error } \\
\%\end{array}$} \\
\hline & $\%$ & $\mathrm{P}$ & $\%$ & $\mathrm{P}$ & $\%$ & $\mathrm{P}$ & \\
\hline Total elongation & 20.87 & 0.0008 & 1.59 & 0.1941 & 12.31 & 0.1194 & 65.22 \\
\hline Start of growth & 0.00 & 0.5132 & 3.90 & 0.2879 & 17.06 & 0.0568 & 78.99 \\
\hline Find of growth & 0.00 & 0.7458 & 6.96 & 0.1535 & 0.04 & 0.2549 & 92.99 \\
\hline Duration of growth & 0.00 & 0.6408 & 6.56 & 0.3824 & 14.82 & 0.0437 & 78.62 \\
\hline Rate of elongation & 14.18 & 0.0014 & 3.33 & 0.0842 & 0.00 & 0.7750 & 82.47 \\
\hline Scedling height & 15.93 & 0.0150 & 2.58 & 0.1348 & 18.39 & 0.1297 & 62.99 \\
\hline Basal dianoter & 23.31 & $<0001$ & 1.73 & 0.1737 & 0.00 & 0.8649 & 74.95 \\
\hline Needle dry wejght & 17.20 & $<0001$ & 3.87 & 0.0931 & 0.00 & 0.9898 & 78.90 \\
\hline Branch dry weight & 12.29 & 0.0045 & 2.60 & 0.2610 & 0.00 & 0.9630 & 85.10 \\
\hline Stem dry weight & 13.60 & 0.0027 & 0.00 & 0.5125 & 0.00 & 0.9754 & 86.40 \\
\hline Total dry weight & 16.30 & 0.0003 & 0.99 & 0.3772 & 0.110 & 0.9857 & 82.70 \\
\hline Principal Comp. I & 21.20 & 0.0006 & 0.00 & 0.5395 & 0.60 & 0.9613 & 78.80 \\
\hline
\end{tabular}


of the total variation. Thus, further analyses were conducted using only PRIN1 as a variable representing the variation across the traits. Contribution of individual traits to PRIN1 was very even, with eigenvector values from 0.31 for rate of growth to 0.41 for stem dry weight. Positive and larger values of PRIN1 corresponded to larger seedlings, with larger values of seedling height, total elongation, basal diameter, and rate of elongation, and more dry weight for needles, branches and stem. In contrast, more negative values corresponded to smaller seedlings with lower seedling height, total elongation, basal diameter, and rate of elongation, and less dry weight for needles, branches and stem.

There were highly significant differences among populations for PRIN1 ( $P=0.0006$, Table 2), confirming a strong genetic differentiation among populations for the quantitative traits.

The average per population of first principal component values had a strong and significant association, as indicated by the regression analysis, with all climatic variables. The best fit was when regressing against frost free period, using a quadratic model $\left(\mathrm{r}^{2}=0.90\right.$, $P=0.0001$, Figure 2), although a linear model yielded also a significant fit $\left(\mathrm{r}^{2}=0.87, P=0.0001\right)$. An stepwise multiple regression analysis confirmed that the best predictor of the average per population of first principal component values was frost free period $(P=0.0001)$; no other climatic variable remained in the multiple regression model after frost free period was in (threshold: $P=0.15)$. Other climatic variables were also highly significant when they were individually regressed, using either a linear or a quadratic model; for example: mean annual temperature (linear model: $\mathrm{r}^{2}=0.81, P=0.0001$; quadratic: $\left.\mathrm{r}^{2}=0.86, P=0.0001\right)$, mean annual precipitation (linear model: $\mathrm{r}^{2}=0.82, \quad P=0.0001$; quadratic: $\mathrm{r}^{2}=0.88, P=0.0001$ ), degree days (linear model: $\mathrm{r}^{2}=0.81$, $P=0.0001$; quadratic: $\left.\mathrm{r}^{2}=0.86, P=0.0001\right)$, and annual aridity index (linear model: $\mathrm{r}^{2}=0.82, P=0.0001$; quadratic: $\left.\mathrm{r}^{2}=0.87, P=0.0001\right)$ of the provenances. Those variables usually have demonstrated relevance as primary factors controlling the distribution of biomes and plant species (TUHKANEN, 1980; REHFELDT, 2006; REHFELDT et al., 2006). All this suggests a strong climatic cline, where populations originating in warmer (longer frost free periods), dryer sites, in general, had larger seedlings (larger positive values of first principal component) than populations from colder (shorter frost free periods), more humid sites (populations with more negative values of PRIN1) (Figure 2).

The pattern of genetic differentiation among populations also follows an altitudinal cline, with lowaltitude populations producing larger seedlings (larger positive values of PRIN1), and high-altitude populations with smaller seedlings (more negative PRIN1 values; linear model $\mathrm{r}^{2}=0.82, P=0.0001$; quadratic: $\mathrm{r}^{2}=0.86$, $P=0.0001$; Figure 3 ). This can be explained by the very strong association between altitude of the provenances and the climate values. Altitude was always highly significant when regressed against frost free period $\left(\mathrm{r}^{2}=0.97, \quad P=0.0001\right)$, mean annual temperature $\left(\mathrm{r}^{2}=0.99, \quad P=0.0001\right)$, mean annual precipitation $\left(r^{2}=0.99, P=0.0001\right)$, degree days $\left(r^{2}=0.98, P=0.0001\right)$, and annual aridity index $\left(\mathrm{r}^{2}=0.99, P=0.0001\right)$.

This climatic and altitudinal pattern apparently results from differential selection pressures along the climatic gradient (THomAs, 2011). It was more pronounced than the one found for the same provenances with 7- and 18-month-old seedlings in a nursery test conducted by ViVEROS-VIVERos et al. (2009). The results coincide also with a pronounced altitudinal pattern found for P. pseudostrobus populations originating along an altitudinal gradient and grown in a common garden test (SÁENZ-ROMERO et al., 2012b).

\section{Re-delineation and use of climatic and altitudinal fixed seed zones without considering climatic change}

Altitudinal seed zones proposed by VIVEROS-VIVERos et al. (2009) were re-delineated using the least significant differences among populations (LSD, $\alpha=0.2$ ) for the first principal component. The value of LSD (1.26) was translated to the climatic difference that makes two populations statistically different for frost free period (FFP),

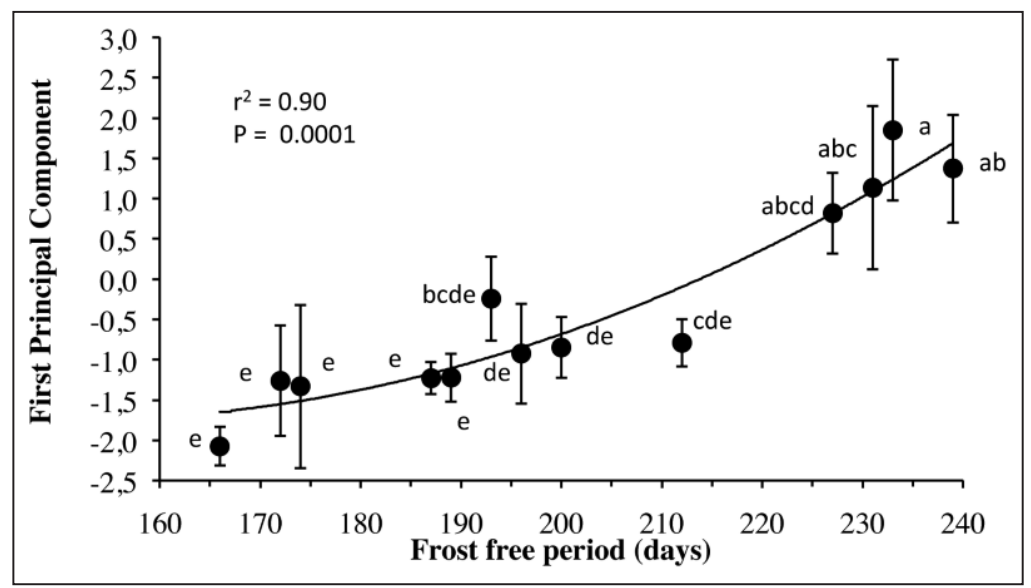

Figure 2. - Population averages for first principal component (larger positive values indicate larger seedlings, lower negative values indicate smaller seedlings) fitted against provenance frost free period. Vertical lines indicate standard error. Different letters indicate mean grouping according to least significant differences $(\alpha=0.05)$ test. 


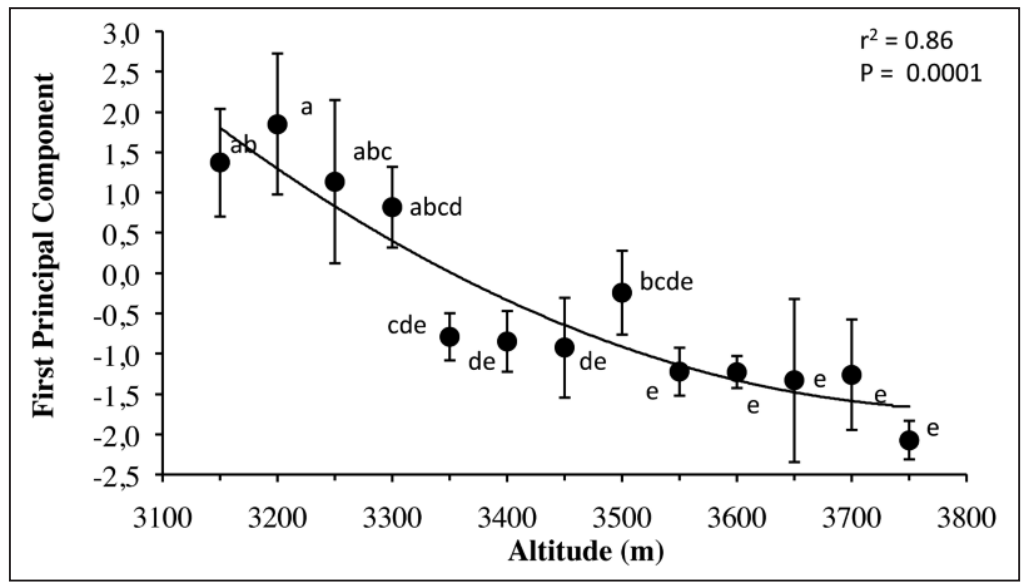

Figure 3. - Population averages for first principal component (larger positive values indicate larger seedlings, lower negative values indicate smaller seedlings) fitted against provenance altitude (masl). Vertical lines indicate standard error. Different letters indicate mean grouping according to least significant differences $(\alpha=0.05)$ test.

because it was the climatic variable that best predicted the principal component values for growth traits. The resulting equivalence of the LSD, using for simplicity a linear regression model [PRIN $1=-9.76+(0.04663$ FFP)], was 27 days of frost free period. Then, by using the linear regression between FFP and altitude [altitude $=5009.93+(-7.74309 \mathrm{FFP})]$, we found the altitudinal difference that makes two populations statistically different, resulting in $209.2 \mathrm{~m}$ of altitudinal difference. That value was rounded to $200 \mathrm{~m}$, aiming for maximum simplicity for forest managers when using altitudinal seed zones. Such interval is equivalent to 26 days of difference in frost free period.

Seed zones where then re-delineated, aiming to cover all the altitudinal distribution of the species in the studied area. We started on the frost free period value predicted for the population that occurs at the lowest altitude (240 days), and delimited the fixed zone climatic interval limits every 26 days of difference in frost free period, resulting three fixed zones: Zone 1, 240 to 214 days of frost free period; Zone 2, 214 to 188 days; and Zone 3, 188 to 162 days. Then, we found their equivalence in altitudinal limits: Zone 1, 3150 to 3350 masl; Zone 2, 3350 to 3550 masl; and Zone 3, 3550 to 3750 masl. Finally, in order to have the equivalence of the zoning on other climatic variables (more commonly used and more familiar for field foresters), we translatedback fixed zone climatic interval limits on annual temperature, precipitation, degree days and annual aridity index, using the respective regression parameters of the association between altitude and each of the other climatic variables. The results are summarized in Table 3, where the fixed zone climatic intervals are defined by interval widths of $1.0^{\circ} \mathrm{C}$ of mean annual temperature, $45.2 \mathrm{~mm}$ of mean annual precipitation, 335 degree days and 0.0043 index value of annual aridity index (Table 3).

Table 3. - Climatic and elevation limits of three fixed seed zones for P. hartwegii for contemporary climate.

\begin{tabular}{|c|c|c|c|c|c|c|c|c|c|c|c|c|}
\hline \multirow[t]{3}{*}{ Zone } & \multicolumn{4}{|c|}{ Altitude (masl) } & \multicolumn{4}{|c|}{ Frost free period (days) } & \multicolumn{4}{|c|}{ Mean anual temperature $\left({ }^{\circ} \mathrm{C}\right)$} \\
\hline & \multicolumn{2}{|c|}{$\begin{array}{c}\text { Limits } \\
(\mathrm{m})\end{array}$} & \multirow[t]{2}{*}{$\begin{array}{c}\text { Range } \\
\text { (m) }\end{array}$} & \multirow[t]{2}{*}{$\begin{array}{l}\text { Interval } \\
\qquad( \pm)\end{array}$} & \multicolumn{2}{|c|}{$\begin{array}{l}\text { Limits } \\
\text { (days) }\end{array}$} & \multirow[t]{2}{*}{$\begin{array}{l}\text { Range } \\
\text { (days) }\end{array}$} & \multirow[t]{2}{*}{$\begin{array}{c}\text { Interval } \\
( \pm)\end{array}$} & \multicolumn{2}{|c|}{$\begin{array}{c}\text { Limits } \\
\left({ }^{\circ} \mathrm{C}\right)\end{array}$} & \multirow[t]{2}{*}{$\begin{array}{c}\text { Range } \\
\left({ }^{\circ} \mathrm{C}\right)\end{array}$} & \multirow[t]{2}{*}{$\begin{array}{c}\text { Interval } \\
( \pm)\end{array}$} \\
\hline & Lower & Upper & & & Lower & Upper & & & Lower & Upper & & \\
\hline 1 & 3150 & 3350 & 200 & 100 & 240 & 214 & 26 & 13 & 12.0 & 11.0 & 1.0 & 0.5 \\
\hline 2 & 3350 & 3550 & 200 & 100 & 214 & 188 & 26 & 13 & 11.0 & 10.0 & 1.0 & 0.5 \\
\hline 3 & 3550 & 3750 & 200 & 100 & 188 & 162 & 26 & 13 & 10.0 & 9.0 & 1.0 & 0.5 \\
\hline
\end{tabular}

(Continuation of Table 3).

\begin{tabular}{|c|c|c|c|c|c|c|c|c|c|c|c|c|}
\hline \multirow[t]{3}{*}{ Zone } & \multicolumn{4}{|c|}{ Degree days $>5^{\circ} \mathrm{C}$ (grades) } & \multicolumn{4}{|c|}{ Precipitation (mm) } & \multicolumn{4}{|c|}{ Annual aridity index (index) } \\
\hline & \multicolumn{2}{|c|}{$\begin{array}{l}\text { Limits } \\
\text { (grades) }\end{array}$} & \multirow[t]{2}{*}{$\begin{array}{l}\text { Range } \\
\text { (grades) }\end{array}$} & \multirow[t]{2}{*}{$\begin{array}{c}\text { Interval } \\
( \pm)\end{array}$} & \multicolumn{2}{|c|}{$\begin{array}{l}\text { Limits } \\
(\mathrm{mm})\end{array}$} & \multirow[t]{2}{*}{$\begin{array}{l}\text { Range } \\
(\mathrm{mm})\end{array}$} & \multirow[t]{2}{*}{$\begin{array}{c}\text { Interval } \\
( \pm)\end{array}$} & \multicolumn{2}{|c|}{$\begin{array}{l}\text { Limits } \\
\text { (index) }\end{array}$} & \multirow[t]{2}{*}{$\begin{array}{l}\text { Range } \\
\text { (index) }\end{array}$} & \multirow[t]{2}{*}{$\begin{array}{c}\text { Interval } \\
( \pm)\end{array}$} \\
\hline & Lower & Upper & & & Lower & Upper & & & Lower & Upper & & \\
\hline 1 & 2553 & 2218 & 335 & 167.5 & 1183 & 1228 & 45 & 22.5 & 0.0427 & 0.0384 & 0.0043 & 0.0021 \\
\hline 2 & 2218 & 1883 & 335 & 167.5 & 1228 & 1273 & 45 & 22.5 & 0.0384 & 0.0341 & 0.0043 & 0.0021 \\
\hline 3 & 1883 & 1548 & 335 & 167.5 & 1273 & 1318 & 45 & 22.5 & 0.0341 & 0.0298 & 0.0043 & 0.0021 \\
\hline
\end{tabular}


Table 4. - Climatic and elevation limits of three fixed seed zones for P. hartwegii for climate projected for year 2030.

\begin{tabular}{|c|c|c|c|c|c|c|c|c|}
\hline \multirow[t]{4}{*}{ Zone } & \multicolumn{4}{|c|}{ Altitude (masl) } & \multicolumn{4}{|c|}{ Frost free period (days) } \\
\hline & \multirow{2}{*}{\multicolumn{2}{|c|}{$\begin{array}{l}\text { Limits } \\
(\mathrm{m})\end{array}$}} & \multirow{3}{*}{ Range (m) } & \multirow{3}{*}{$\begin{array}{c}\text { Interval } \\
( \pm)\end{array}$} & \multirow{2}{*}{\multicolumn{2}{|c|}{$\begin{array}{l}\text { Limits } \\
\text { (days) }\end{array}$}} & \multirow{3}{*}{ Range (days) } & \multirow{3}{*}{$\begin{array}{c}\text { Interval } \\
( \pm)\end{array}$} \\
\hline & & & & & & & & \\
\hline & Lower & Upper & & & Lower & Upper & & \\
\hline $1_{2030}$ & 3550 & 3750 & 200 & 100 & 240 & 214 & 26 & 13 \\
\hline $2_{2030}$ & 3750 & 3950 & 200 & 100 & 214 & 188 & 26 & 13 \\
\hline $3_{2030}$ & 3950 & 4150 & 200 & 100 & 188 & 162 & 26 & 13 \\
\hline
\end{tabular}

In this way, forest managers can chose to use either altitude or climatic values to decide their seed and seedling movements.

This zoning has narrower fixed zone elevation intervals than that delimited by ViVERos-Viveros et al. (2009), which had altitudinal bands of $350 \mathrm{~m}$ based on 18-month-old seedling characteristics. It is possible that if we had had more than one test site established at locations nearer or inside the $P$. hartwegii natural stands, the magnitude of the expressed genetic variation among populations might have been different, due to possible genotype $\mathrm{x}$ environment interaction effects, and therefore, the seed zone elevation intervals might have resulted in a different width.

Suitable guidelines for reforestation for ecological restoration and conservation, without taking into account the potential effects of climatic change, would be (a) reforestation of a given fixed seed zone using seedlings originating from the same fixed seed zone, or alternatively, (b) to reforest a site at a given altitude using seedlings originating from seed collected from $\pm 100 \mathrm{~m}$ in altitude or \pm 13 days of frost free period or \pm 0.5 of mean annual temperature or \pm 167.5 degree days or $\pm 22.5 \mathrm{~mm}$ of precipitation or \pm 0.0021 of annual aridity index value from the site to be reforested (half the width of a climatic interval or altitudinal interval).
The second approach is known also as focal point zones. However, those recommendations to use local seed are given ignoring the potential effects of the climatic change.

\section{Realigning genotypes to match year 2030 climate and dilemmas to face}

Future fixed zone altitudinal intervals limits were estimated based on the prediction of the altitude at which will occur for year 2030 (averaging the six modelscenarios projections) the frost free days values that defined the contemporary (Table 3 ) fixed zone intervals limits. The estimated limits of three fixed seed zones were: 3542 , 3740, 3939 and 4137 masl. That indicated a consisted interval width of $198 \mathrm{~m}$ of altitudinal difference in average. For simplification, we rounded the interval width to $200 \mathrm{~m}$, and re-delineated the future fixed zone altitudinal intervals limits as: Zone $1_{2030}$, 3550 to 3750 masl; Zone $2_{2030}$, 3750 to 3950 masl; and Zone $3_{2030}$, 3950 to 4150 masl (Table 4 ).

Notice on the future fixed seed zones (Table 4) that: (a) Altitudinal intervals limits will mean an altitudinal shift upwards of $400 \mathrm{~m}$ of altitude, as result of the displacement of the frost free period that we know on our contemporary climate to higher altitudes on year 2030 (Figure 4). (b) Part of the Zone $2_{2030}$ and all the Zone

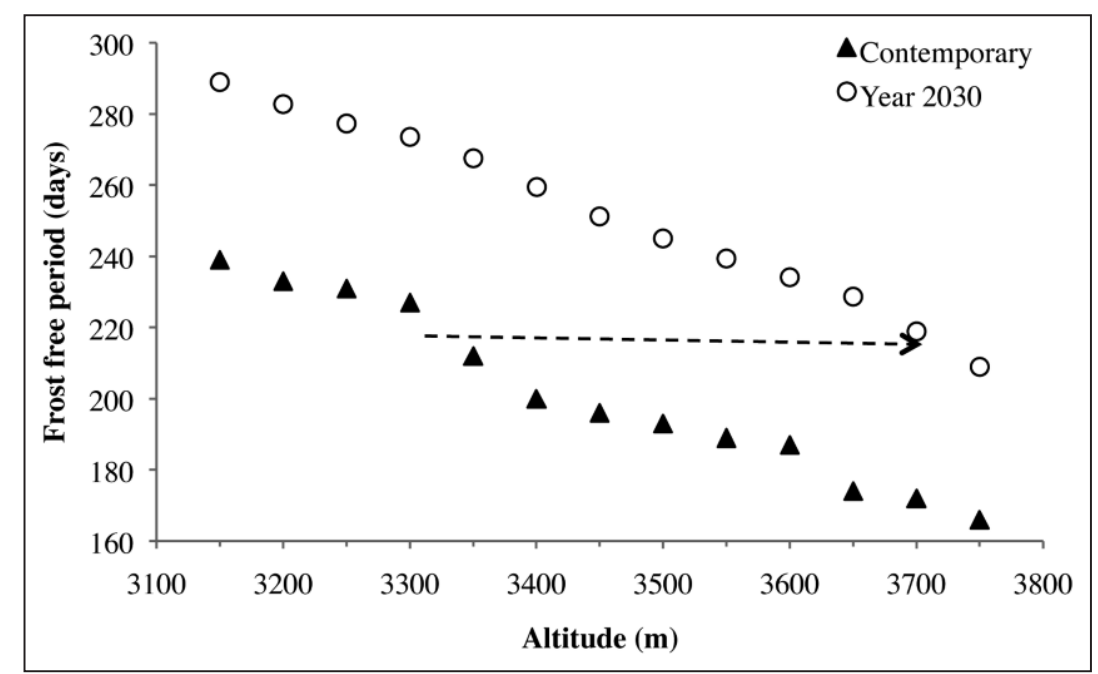

Figure 4. - Provenance frost free period of contemporary and year 2030 climate (average among six model-scenarios projections) plotted against provenance altitude. Arrow indicates upward altitudinal movement needed $(400 \mathrm{~m})$ to match a given frost free period value for which a population is adapted at present but will occur at higher elevation in year 2030. 
$3_{2030}$ exceeds the maximum altitude of Pico of Tancítaro, that is of $3840 \mathrm{~m}$ (we discuss this issue later), and (c) The frost free period values that define the zone interval limits are the same one than for contemporary zones showed on Table 3 .

Thus, assuming that frost free period is a reliable indicator of the climate suitable for a given population (Figure 2), in order to realign the genotypes to the climate for which they are adapted and that will occur by year 2030, it will be need the simultaneous use of the contemporary and future fixed zones as the following example: to collect seeds from contemporary seed Zone 1 (Table 3), produce seedlings in the nursery, and plant on the corresponding future Zone $1_{2030}$ (Table 4). That will mean a shift upwards of $400 \mathrm{~m}$ in average.

However, a movement of more than $200 \mathrm{~m}$ of altitude at present, the width of the proposed fixed seed zone elevation intervals, might implicate running the risk of frost damage (SÁENZ-ROMERO and TAPIA-OLIVARES, 2008). Unfortunately, Pinus hartwegii has a very slow growth rate, compared to other Mexican pines (leaving aside the pinyon pines), to conduct the assisted migration in two steps (e.g. move $200 \mathrm{~m}$ upwards and then another 200 $\mathrm{m})$ to match the climate projected for year 2030 .

Thus, forester will face the dilemma of what risk to run: (a) to move upwards $400 \mathrm{~m}$ of altitude and likely to have risk of frost damage occurring earlier after the plantation were established, although if seedlings survive, to have later the genotypes matched to the projected climate for 2030, or, (b) to move upwards only $200 \mathrm{~m}$ of altitude, to have minimized the risk of frost damage occurring earlier after plantation and consequently to have more probabilities of seedling survivorship, although to have later a partial decoupling between the genotypes and the climate projected for year 2030 .

Perhaps the best approach is to move $400 \mathrm{~m}$ upwards and find the way to minimize the frost damage right after plantation, using nurse plants that could protect the $P$. hartwegii plants of frost damage. Lupinus elegans was successfully used as nurse plants protecting of extreme temperatures planted seedlings of Abies religiosa in a site near of Pico de Tancítaro, although at lower elevation ( $2800 \mathrm{~m}$ of altitude) (BLANCO-GARCíA et al., 2011). Nurse plants might need to be planted at least one year in advance, and probably to use a nurse plant species adapted to higher altitudes than Lupinus elegans, like Lupinus montanus.

In practice, when procuring seed $400 \mathrm{~m}$ below the target site, it would be reasonable to apply the $\pm 100 \mathrm{~m}$ focal point zones criterion; in other words, seeds from locations that are 500 to $300 \mathrm{~m}$ lower than the plantation site could be used.

The suggested upward shift would require a massive reforestation program. However, if the shift is not conducted, the forests will likely begin a gradual process of decline due to the increasing mismatch between the populations and the climate for which they are adapted (Allen et al., 2010; MÁTYÁs, 2010; MÁTYÁs et al., 2010). There is evidence that for some tree species upward altitudinal migration is occurring already, but at a speed far below what is needed to maintain the match between tree populations and their suitable climatic habitat (Peñuelas al., 2007; LenOIR et al., 2008). In fact, a growth decline for $P$. hartwegii populations in Mexican mountains has been detected, apparently due to the climatic change that has already occurred (RICKER et al., 2007).

The upward altitudinal shift of $P$. hartwegii populations would have as an absolute limit the summit of their respective mountains. Thus, the upward shift of populations that are near or at the summits would require establishing populations on different mountain ranges to match the climate of 2030 . In the case of Pico de Tancítaro, Michoacán, the populations near the 3840 masl summit might need to be moved to elsewhere, for example to the flanks of the highest volcanoes in México, such as Nevado de Toluca, Popocatépetl, Iztaccíhuatl, La Malinche and Citlaltépetl, in a similar fashion as was suggested that the Abies religiosa populations near the summits of the Monarch Butterfly Biosphere Reserve be moved to different mountains and flanks of high volcanoes (SÁENZ-ROMERo et al., 2012a).

\section{Conclusions}

There is genetic differentiation among populations for total elongation, rate of elongation, final seedling height, basal diameter, dry weight of needles, branches, stem, total dry weight and first principal component of five-year-old seedlings.

Genetic differentiation among populations follows a pronounced climatic and altitudinal cline, where populations originating in warmer, dryer and lower altitudes in general have larger seedlings (larger total elongation, rate of elongation, final seedling height, and basal diameter) and accumulate more dry weight in needles, branches and stem than populations originating in colder, more humid and higher altitude sites.

Three climatic and altitudinal zones of 26 days of frost free period or $1^{\circ} \mathrm{C}$ of mean average temperature or 200 $\mathrm{m}$ of altitudinal difference as width were re-delineated: Zone 1, from 240 to 214 days of frost free period or 12 to $11^{\circ} \mathrm{C}$ or 3150 to 3350 masl; Zone 2,214 to 188 days or 11 to $10^{\circ} \mathrm{C}$ or 3350 to $3550 \mathrm{masl}$; and Zone 3, 188 to 162 days or 10 to $9^{\circ} \mathrm{C}$ or 3550 a 3750 masl. Reforestation programs should use seedlings originating in the same seed zone where they will be planted, if they are not considering effects of climatic change.

A $400 \mathrm{~m}$ upward shift of seed sources is suggested, to match the genotypes and the climate for which they are adapted and that will occur at higher altitude sites by year 2030.

\section{Acknowledgements}

This paper is an undertaking of the Forest Genetic Resources Working Group/North American Forest Commission/Food and Agricultural Organization of the United Nations. Financial support to CSR was provided by the joint research funds from the Mexican Council of Science and Technology, together with the Mexican National Forestry Commission (CONACyT-CONAFOR2005- C02-14783), and the State of Michoacán (CONA- 
CyT-Michoacán-2009-127128), as well as a grant from the Coordination for Scientific Research of the University of Michoacán (UMSNH-CIC). We thank FELIPE Aguilar, Rafael EcheverRía, Reyes Aguilar (Forestry Office of Nuevo San Juan Parangaricutiro Native Indian Community), Miguel A. Silva, Rodrigo Niniz, HÉctor Viveros, Victor H. Cambrón, José C. Soto, César Chávez, Gustavo Olalde (UMSNH) and others for their help in seed collection, establishment and maintenance of the common-garden experiment in early stages; M. Consuelo Marín-Togo prepared the map. Comments by GERALD E. REHFELDT and two anonymous reviewers helped to improve significantly the manuscript.

\section{References}

Allen, C. D., A. K. Macalady, H. Chenchouni, D. BAChelet, N. MCDowell, M. Vennetier, T. KizBerger, A. Rigling, D. D. Breshears, E. H. Hogg, P. Gonzalez, R. Fensham, Z. Zhang, J. Castro, N. Demidova, J. H. Lim, G. Allard, S. W. Running, A. Semerci and N. CobB (2010): A global overview of drought and heat-induced tree mortality reveals emerging climate change risks for forests. Forest Ecology and Management 259: 660-684.

Blanco-García, A., C. SÁenz-Romero, C. Martorell, P. AlvarAdo-Sosa and R. Lindig-Cisneros (2011): Nurse plant and mulching effects on three conifer species in a Mexican temperate forest. Ecological Engineering 37: 994-998.

Crookston, N. L. and G. E. REHFELDT (2011): Research on Forest Climate Change: Potential Effects of Global Warming on Forests and Plant Climate Relationships in Western North America and Mexico. http:/ forest.moscowfsl.wsu.edu/climate/. Updated November 2011.

Gómez-MendozA, L. and L. ArRiaga (2007): Modeling the effect of climate change on the distribution of oak and pine species of Mexico. Conservation Biology 21: 1545-1555.

LAUER, W. (1978): Timberline studies in central Mexico. Artic Alpine Res. 10: 383-396.

Lenoir, J., J. C. GÉgout, P. A. Marquet, P. de Ruffray and H. BRISSE (2008): A significant upward shift in plant species optimum elevation during the $20^{\text {th }}$ century. Science 320: 1768-1771.

MátYÁs, C. (2010): Forecasts needed for retreating forests. Nature 464: 1271.

Mátyás, C., I. Berki, B. Czúcz, B. Gálos, N. Móricz and E. RAszTovits (2010): Future of beech in Southern Europe from the perspective of evolutionary ecology. Acta Silvatica et Lignaria Hungarica 6: 91-110.

Peñuelas, J., R. Oyaga, M. BoadA and A. S. Jump (2007): Migration, invasion and decline: changes in recruitment and forest structure in a warming-linked shift of European beech forest in Catalonia (NE Spain). Ecography 30: $830-838$.

PerRy, J. P. (1991): The Pines of Mexico and Central America. Timber Press. Portland, Oregon, USA.

REHFELDT, G. E. (1991): A model of genetic variation for Pinus ponderosa in the Inland Northwest (USA): applications in gene resource management. Can. J. For. Res. 21: 1491-1500.

REHFELDT, G. E. (2006): A spline model of climate for the Western United States. Gen. Tech. Rep. RMRS-GTR165. U.S. Department of Agriculture, Forest Service, Rocky Mountain Research Station, Fort Collins, Colorado, USA.
Rehfeldt, G. E., N. L. Crookston, M. V. Warwell and J. S. Evans (2006): Empirical analyses of plant-climate relationship for the western United States. International Journal of Plant Sciences 167(6): 1123-1150.

Rehfeldt, G., N. Crookston, C. Sáenz-Romero and E. CAMPBELL (2012): North American vegetation model for land-use planning in a changing climate: a solution to large classification problems. Ecological Applications 22: 119-141.

Ricker, M., G. GutiÉRrez-García and D. C. Daly (2007): Modeling long-term tree growth curves in response to warming climate: test cases from a subtropical mountain forest and a tropical rainforest in México. Canadian Journal of Forest Research 37: 977-989.

SÁenz-Romero, C., R. Guzmán-Reyna and G. E. Rehfeldt (2006): Altitudinal genetic variation among Pinus oocarpa populations in Michoacán, México; implications for seed zoning, conservation of forest genetic resources, tree breeding and global warming. Forest Ecology and Management 229: 340-350.

SÁEnZ-Romero, C. and B. L. TAPIA-Olivares (2008): Genetic variation in frost damage and seed zone delineation within an altitudinal transect of Pinus devoniana (Pinus michoacana) in Mexico. Silvae Genetica 57: 165-170.

SAénz-Romero, C., G. E. Rehfeldt, N. L. Crookston, P. Duval, R. St-Amant, J. Beaulieu and B. A. RichardSON (2010): Spline models of contemporary, 2030, 2060 and 2090 climates for Mexico and their use in understanding climate-change impacts on the vegetation. Climatic Change 102: 595-623.

Sáenz-Romero, C., G. E. Rehfeldt, P. Duval and R. A. Lindig-Cisneros (2012a): Abies religiosa habitat prediction in climatic change scenarios and implications for monarch butterfly conservation in Mexico. Forest Ecology and Management 275: 98-106.

Sáenz-Romero, C., G. E. Rehfeldt, J. C. Soto-Correa, S. Aguilar-Aguilar, V. Zamarripa-Morales and J. LÓPEZ-UPTON (2012b): Altitudinal genetic variation among Pinus pseudostrobus populations from Michoacán, Mexico. Two location shadehouse test results. Revista Fitotecnia Mexicana 35(2): 111-120.

SAS Institute InC. (2004): SAS/STAT Computer Software. Release 9.1. $3^{\text {rd }}$ Edition. SAS Institute Inc, Cary, North Carolina, USA.

Tchebakova, N. M., G. E. Rehfeldt and E. I. PARfEnova (2005): Impacts of climate change on the distribution of Larix spp. and Pinus sylvestris and their climatypes in Siberia. Mitigation and Adaptation Strategies for Global Change 11: 861-882.

Thomas, S. C. (2011). Genetic vs. phenotypic responses of trees to altitude. Tree Physiology 31: 1161-1163.

Tukanen, S. (1980) Climatic parameters and indices in plant geography. Acta Phytogreographica Suecica 67: 1-105.

Viveros-Viveros, H., C. SÁenz-Romero, J. J. VArgasHERnÁNDEZ, J. LÓPEZ-UPTON, G. RAMírez-VALVERDE and A. SANTACRUZ-VARELA (2009): Altitudinal genetic variation in Pinus hartwegii Lindl. I: Height growth, shoot phenology, and frost damage in seedlings. Forest Ecology and Management 257: 836-842.

Viveros-Viveros, H., B. L. Tapia-Olivares, C. SáenzROMERO, J. J. VARGAS-HERNÁNDEZ, J. LÓPEZ-UPTON, A. SANTACRUZ-VARELA and G. RAmíREZ-VALVERDE (2010): Isoenzymatic variation of Pinus hartwegii Lindl. along an altitudinal gradient in Michoacán, México. Agrociencia 44: 723-733. 